\title{
Words, Characters, and Context: Giovan Maria Cecchi and the Language of Theatre
}

\section{KonRAD EISENBICHLER}

Summary: With over sixty plays to his credit, the Florentine notary Giovan Maria Cecchi (1518-87) was the most prolific Italian dramatist of the entire Renaissance. Not surprisingly, his fellow Florentines nicknamed him il Comico (the playwright) not only because of his great productivity, but also because of the unquestioned success of his works. In fact, his plays seemed to please audiences that ran the gamut from adolescent boys in confraternities to the grand-ducal court, from cloistered nuns in convents to carnival brigades of carefree young men. Clearly, Cecchi knew something about theatre and about audiences that worked to his advantage. This article proposes that Cecchi's dramatic talent rested, in part, on his keen sense of language and on his ability to adapt it as required not only by the plots and characters of his plays, but also by his audiences, their context, and the changing social political situation of sixteenth-century Florence.

The Florentine notary Giovan Maria Cecchi (1518-87) is known today not for his legal career, but for the plays he composed. With over sixty dramatic texts to his credit, he is by far the most prolific Italian dramatist of the entire Renaissance. ${ }^{1}$ None of the other even comes close to his enormous output for the stage. Not surprisingly, Cecchi was known to his contemporaries as il Comico, ("the comedywriter" or, simply, "the playwright"), ${ }^{2}$ and rightly so. From 1544 to the year of his death, Cecchi wrote at least a play a year, each one on commission by fellow Florentines and for immediate performance. He was, in short, both productive and sought after. He was also a versatile. As a dramatist he experimented with quite a variety of genres, from standard learned comedies to innovative religious dramas, from tragedy to farces, from devotional interludes to one-act plays. And the results

\footnotetext{
${ }^{1}$ For the most recent catalogue of Cecchi's works, see Ferraro, "Catalogo delle opere di G. M. Cecchi."

${ }^{2}$ Luigi Fiacchi in his letter to Gaetano Poggiali, published in Cecchi, Le maschere e Il Samaritano, p. xxiii.
} 
were well received - audiences clearly loved his plays and flocked to see them, so much so that at least one of his rivals, the sharp-tongued wit Antonfrancesco Grazzini, did not hesitate to lampoon him for his success. In a two-octaves poem replete with professional jealousy, Grazzini describes how Cecchi had become the toast of the town, especially with the female public, much to the dismay of other Florentine dramatists:

A giudizio del popol fiorentino e delle donne, che più pesa e grava, il Cecchi ha vinto e superato il Cino che prima era un poeta a scaccafava; or, come avesse spirito divino, se ne va altero e sgonfia e sbuffa e brava, dato avendo al Buonanni anco la stretta, e il Lasca sguizza e Frosino sgambetta.

Ponete mente a Lotto calzaiuolo, com'egli è malcontento e sbigottito; e Lionardo Salviati muor di duolo, per che il suo Granchio fu tanto schernito.

Ser Tarsia se ne va ramingo e solo che proprio pare un comico fallito; dappoi che quest'ingegni loschi e sordi mettono il Cecchi nel ciel de' balordi. ${ }^{3}$

(In the opinion of the Florentine people / and of the women, which weighs more and counts, / Cecchi has conquered and surpassed

\footnotetext{
${ }^{3}$ Grazzini, Le rime burlesche, p. 422, poem xcii. The various fellow dramatists mentioned in the octaves are: Giovan Battista Cini (1528-c.1586), author of at least two comedies, La vedova (1566-69) and Il baratto (1577); Vincenzo Buonanni (life dates unknown), author of a Discorso on the first canticle of Dante's Commedia (1572), but none of his works for the theatre have survived; Antonfrancesco Grazzini himself (1503-84), author of at least nine plays; Frosino Lapini (c.1520-1571), erudite and scholar, editor of two of Francesco D'Ambra's plays, but we have no record of any of his own works for the stage; Lotto Del Mazza (d. 1597), author of at least two plays, I Fabii (1567) and Il ricatto (1578); Lionardo Salviati (1540-89), author of at least two plays, Il Granchio (1566) and La spina (1570); and Giovan Maria Tarsia (life dates unknown), most famous for his funeral oration on the death of Michelangelo in 1564, but we have no record of any of his works for the stage.
} 
Cino, / who, before, was a winning poet; / so that now, as if imbued with a divine spirit, / he goes along haughty and puffed up, and huffs and lords it, / and he has even put Buonanni in a tight spot, / and Lasca slips away and Frosino trips up. // Think of Lotto, the cobbler, / how unhappy and bewildered he is; / and Lionardo Salviati is dying of grief, / because his Granchio was so derided. / Ser Tarsia wanders about alone, / very much looking like a failed playwright; / eversince these shady and deaf intellects / have placed Cecchi in a fool's paradise.)

Although in the seventeenth and eighteenth centuries Cecchi's reputation as a dramatist suffered a set-back because of changing tastes in theatre, in the nineteenth and twentieth centuries it enjoyed a rapid resurgence leading to the (re) edition of most of his works, a good amount of scholarly discussion of his plays, and even the translation of some of his works into English. Whatever the reasons for Cecchi's success both in his lifetime and posthumously, it is clear that one of them lies in his ability to use the language of theatre to great effect. This article will thus examine three specific aspects (among many) of Cecchi's "language of theatre" and how he used them to reach out to delight his audience: his use of the local spoken idiom, his portrayal of various character types through careful linguistic choices, and his readiness to revise the language of his plays in order to adapt them to the performers and the audience.

The first and foremost aspect of Cecchi's language for the stage is the idiom he uses, that is, the Florentine vernacular. A passionate lover of his native tongue, in his plays Cecchi delights in the effective choice of words and revels in the colourful local phrase. His comic figures, especially, speak in a lively Florentine that must have struck a warm familiar note with his audiences and, at key moments, even raised peels of laughter as only the pleasure of a well-turned local phrase can do.

His Florentine vernacular is also highly self-referential, rich in allusions to local landmarks and Tuscan locations. Quite a number of his plays are set in Florence and thus contain direct references to local sites such as the major downtown intersection (the Cardo), or the Mercato Vecchio, or churches such as Santissima Annunziata, streets such as via delle Pinzochere, street-corners such as 
the Canto del Tribolo, and so forth. The wealth of local references contributes to a veritable urban geography of the city that must have resonated with the local audience. Tuscany itself is also present in his plays, sometime by having a play set in a near-by city (L'assiuolo and I rivali, for example, are set in Pisa, La Maiana in a villa outside Fiesole, La serpe ovvero la mala nuora in Siena) and sometime by indirect references to near-by towns. But even when the action is not set in Tuscany the region remains present in Cecchi's works by virtue of the colourful expressions used in the plays, expressions such as the self-explanatory pazzo come un Senese (crazy as a Sienese) or the less evident andare a Girone (a small village outside Florence) to mean "to become crazy" (an allusion to the idiomatic expression gli è girata la testa, "he lost his mind"), or andare a Volterra (to go to Volterra) to mean "to die" (punning on "voltare la terra," to turn the sod over), or venire da Montefiascone (to come from Montefiascone) to describe a drunkard (punning on Monte Fiascone, "Flask Mountain"). ${ }^{4}$ All these expressions provided both local colour and local humour to an audience that was, for the most part, Tuscan.

In using such colourful local expressions Cecchi sets his plays (whether actually or figuratively) in the Tuscan reality of his audience, clearly identifying the action on stage with the everyday world of the spectators. Though most of these references poke fun at neighbouring towns and populations, they nonetheless reveal Cecchi's special feeling for his region, its people, and their language. His pride in being a "home-town boy" is clearly voiced in the prologue to Le maschere (1585) when he describes himself as "a little man, descended from those people who have never lost sight of the dome, or barely." Brunelleschi's famous dome for the cathedral of Florence, a marvel of engineering and a source of pride for Florentines to this day, thus becomes the focal point around which revolve Cecchi's life and world, the identity marker for self and others. It appears in a number of prologues in order to set the scene and provide a reference point for all future action:

Il Proscenio è in Fiorenza, [...]

[...] Ecco la Cupola

Principal contrasegno vostro, bastivi.

(Lo spirito, p. 372)

\footnotetext{
${ }^{4}$ Cecchi, La serpe, II.8, p. 187; Il cieco nato, II.6, p. 331.

5 "un uomiciatto / Fatto dal ceppo, che non ha perduto / la Cupola di vista, o poco." Cecchi, Le maschere, p. 7.
} 
Words, Characters, and Context:

Giovan Maria Cecchi and the Language of Theatre

(The scene is set in Florence [...] / [...] Here is the dome, / your major reference point, it's enough for you.)

voi conoscete che questo proscenio è in Firenze; che 'l Cardo e la Cupola e la Piazza che è qui, ve la figurano assai chiara." (Gl'incantesimi, p. 130)

(You know this scene is in Florence; for the Cardo, the Cupola, and the Piazza that you see here represent it clearly for you.)

Cecchi himself is conscious of his Florentine bias in his comedies, so much so that in the prologue to Le maschere, after having pointed out that the play is set in Florence, he adds that this is something quite common for him because, out of eighteen comedies that he has composed, fourteen are set in the city on the Arno. ${ }^{6}$

Cecchi's Florentine language is replete not only with references to local sites, but also with images and ideas peculiar to a mercantile city such as Florence. His plays abound in expressions such as: dugento libbre di pensieri non pagano dua once pur di debito (two hundred pounds of worries do not pay even two ounces of debit) to mean worrying about a problem will not solve it (La coronazione del re Saul, IV.15); a poltroni fa freddo (lazy people are cold) to mean that unproductive people live uncomfortably (Il Tobia, IV.6). Given Florence's long republican history, it also abounds in expressions that echo that tradition of public service and responsibility; expressions such as il magistrato mostra l'uomo (the office reveals the man) to mean that a person's abilities and moral standing are brought to light by the manner he conducts himself when in a position of responsibility (L'acquisto di Giacobbe, II.2); or il nuovo potestà ne manda il vecchio (the new chief magistrate sends away the old one) to mean that a new political leader is not obligated to do what the previous one wanted (La gruccia, II.3). Many of Cecchi's idioms reveal a strong cynical streak, as is probably natural in a competitive society such as that of Florence: il fiume non ringrossa mai d'acqua chiara (a river never swells with clear water) to mean that people who are too "pure," that is, too honest, never grow rich and powerful (La gruccia, II.2); or chi vuol venir grande in prelature, lasci un po' star gli scrupoli da banda (whoever wants to advance in office must set his scruples aside) to indicate that conscience is a detriment for a successful career in office (Datan e Abiron, II.2).

\footnotetext{
${ }^{6}$ Cecchi, Le maschere, p. 6.
} 
Cecchi's ear for, and interest in the typically Florentine phrase is evident not only in his plays, but also in the anthology of Tuscan proverbs he compiled but did not publish, probably because he meant the collection to be a reference tool for himself and nothing more. His anthology was brought to scholars' attention by the early nineteenth-century erudite Luigi Fiacchi (1754-1825), who first discussed it at a meeting of the Academy of the Crusca on 30 November 1813 and then edited it and published it (1818). ${ }^{7}$ The Academy of the Crusca was founded in 1582, when Cecchi was alive and well, writing prolifically and enjoying great popularity. Among its founders there was Cecchi's fellow dramatist and rival, Antonfrancesco Grazzini, who had been instrumental forty years earlier in founding the academy of the Umidi (1539), a group that Duke Cosimo I de' Medici quickly took over and renamed the Accademia Fiorentina (1540), giving it the official mandate of fostering Tuscan literature and language. Although at first the Academy of the Crusca was born as a burlesque reaction to the classicizing and, in some ways, pedantic activities of the state-sponsored Accademia Fiorentina, it quickly became a serious institution itself, one whose primary purpose was not to mock a sister organization, but to highlight, protect, and foster the "purity" of the Florentine idiom by, as the name of the academy suggests, separating the wheat from the chaff (crusca is the Italian word for chaff). This focus on the Florentine idiom eventually led the Crusca to publish a dictionary, the Dizionario della Crusca, that first appeared thirty years later, in 1612, and served as a model for subsequent French, Spanish, German and English national dictionaries. In the words of John Considine, "This dictionary, more than any other, was the foundation of the scholarly lexicography of the living languages of Europe." ${ }^{8}$ It is, to this day, the official dictionary of the Italian language. Already in its first edition (1612) Giovan Maria Cecchi's plays served as a veritable mother lode for words, phrases, and expressions that exemplified an idiomatically correct Tuscan language. The vitality and verve of Cecchi's language was thus not only striking and effective on stage, but also of fundamental importance for the lexicographers who first set themselves the task of identifying and defining the words and expressions that

\footnotetext{
${ }^{7}$ See Fiacchi, Dei proverbi toscani. Fiacchi republished it in 1820 (Florence: Stamperia Piatti) in an expanded edition that was "aumentata di molti pezzi tratti dalle Commedie inedite del medesimo Cecchi." The essay and appended edition were twice republished posthumously in the nineteenth century: Milan: Giovanni Silvestri, 1838; and Milan: G. Daelli,1863. The Daelli edition was reprinted in facsimile format by Forni (Bologna) in 1974.

${ }^{8}$ Considine, Academy Dictionaries, p. 27; see also the entire first chapter of his book.
} 
constituted "good" Italian. In 1883, three centuries after Cecchi and the founding of the Crusca, another institution, this time the Ministry of Education of a united Italy, reaffirmed the value of Cecchi's linguistic choices by decreeing that his plays were to be included among the texts suitable for use in Italian schools, especially on account of the fine quality of the language in which they were written. ${ }^{9}$

While his contributions to the idiomatic richness of the "official" Italian language are undeniable, Cecchi was too good a dramatist to depend only on the verve and beauty of the local Tuscan idiom for the success of his plays or for ensuring that they captivated his audience. His "language of theatre" also included characters that came alive on stage and could be easily identified and distinguished by the audience. To do so, he had his characters speak in their own voice. And so the country bumpkin who has just arrived in town to run some errands speaks in what is identifiably a more rustic language than the one used by the more urbane city folk he encounters in the city. As the French scholar Jacqueline Brunet pointed out a few years ago, Cecchi's peasants use a vocabulary that is rich in archaic terms and metaphors, in images that are clearly drawn from the agrarian world they inhabit. ${ }^{10}$ In Il Tobia (Nov. 1580), the farmer boy Capocchio uses archaic terms such as bricco, meaning, buricco or small donkey, and avale, meaning "now" (II.2-3). He also objects to his name, Capocchio, a derogatory term referring to unreliable persons lacking in wits, perhaps best translated as "numbskull." The country boy does not want to be known by that name and worries that if he does not change it soon enough it will stick to him into his adulthood:

Io non sono,

Mona Stafira, Capocchio e non voglio

Risponder per quel nome: chè la mamma

\footnotetext{
${ }^{9}$ Lombardi, "Il prologo degl'Incantesimi," p. 75, where he seems not at all convinced of the wisdom of such an "unhoped-for elevation" and waxes sarcastic not only about the decree, but also about Olindo Guerrini's recent edition of six plays by Cecchi (1883). In a more positive tone, see Ferraro, "Introduzione" to Cecchi, I contrassegni, p. xi: "Già nel 1883 la sua rivalutazione ebbe inizio quando con decreto ministeriale Baccelli, le sue opere entrarono fra i libri di testo scolastici in considerazione appunto dei pregi della sua lingua."

${ }^{10}$ Brunet, "Le paysan et son langage" and idem., "Ces mots en cusse."
} 
Dice che e' gli andre' innanzi e s'io crescessi, I' arei un capocchio grande, grande.

(Il Tobia, II.3, p. 30)

(I am not, / Mona Stafira, Capocchio and I don't want / to answer to that name: because my mother / says that it will stick to me and when I grow up / I would be a very big numbskull.)

The rustic figures in Cecchi's plays not only speak an archaic language, but also voice ideas that are identifiably "rural" and not "urbane." In the sacred play Il figliuol prodigo (1570), when the young peasant boy Tognarino comes for the first time to the big city of Florence, he sees a lot of things he does not recognize and has no name for, things such as carnival masks, soldier's armour, and marble statues. Recalling what he had seen in the Piazza della Signoria Tognarino engages his father Bartolo in a series of questions and answers that, inevitably, ends with the child's request to the father to buy him one:

Tognarino. E quegli uomini grandi che erano in su quella piazza ignudi ignudi, e eran tutti bianchi, che énn’ eglino? e che vi facevano?

Bartolo. E' si chiaman gioganti, ed énno di mármero.

Tognarino. E a che énno eglin buoni?

Bartolo. Énno buoni a guatare.

Tognarino. Oh non gli fa eh, lor freddo, babbo?

Bartolo. Oh no, che son di sasso.

Tognarino. E dove nascono?

Bartolo. Oh vi son stati posti da gli uomini.

Tognarino. Pongonsi eglino, come fè l'oste i piantoni?

Bartolo. No che ve gli strainon co' buoi.

Tognarino. Oh Dio, ne vorrei uno! deh compratemene uno e portiamolo a casa!

(Il figliuol prodigo, III.3, p. 32)

(Tognarino. And those big men who stood on the piazza, completely naked, and they were all white, what were they? And what were they doing there? 
Words, Characters, and Context:

Bartolo. They are called giants, and they're made of marble.

Tognarino. And what are they good for?

Bartolo. They're good to look at.

Tognarino. Oh, and aren't they, eh, cold, dad?

Bartolo. Oh no, because they are made of stone.

Tognarino. And where are they born?

Bartolo. Oh, they were put there by men.

Tognarino. Did they put them there like the landlord does the saplings?

Bartolo. No, they drag them there with the bulls.

Tognarino. Oh God, I want one! Come on, buy me one and let's bring it home!)

The rustic language and mentality of Tuscan peasants such as Capocchio, Tognarino, and Bartolo serve to create a humorous moment in the play, as do the various non-Tuscan dialects spoken by "foreign" workers in the city. In La dote (1544), the country bumpkin Magnano speaks with strong Lombard/Venetian tones (IV.7), while in Lo spirito (1549) the porter speaks Lombard (IV.4), in L'ammalata (1555) the zanaiuolo (basket carrier) speaks Sicilian (IV.4), and in Il donzello (1550) the braggart soldier speaks Spanish (I.3) - a plurality of vernaculars that reveals not only Cecchi's fine ear for foreign idioms, but also the variety of languages and dialects one could hear on the street in sixteenth-century Florence. It also points to the variety of idioms a Florentine audience could understand — Florence, after all, was not a back-waters town in sixteenth-century Europe, but a world-class city whose citizens were accustomed to strangers passing through.

In bringing to the stage the languages of non-Tuscans, Cecchi not only depicts the multicultural and polyglot reality of Renaissance Florence (and, by extension, Italy), but also pokes good fun at linguistic differences and at the misunderstandings that can arise from the diversity of languages in current use - all the while suggesting that Tuscan (or, more precisely, Florentine) is the standard language of communication. He implies as much in I rivali (1556), where he also strikes a cruel blow at the much detested Spaniards in Italy. The Prologue to the play tells the audience that:

La scena è in Pisa; quei che ci intervenghono son forestieri; ma però parrannovi 
fiorentini, sì han presa la dolcissima

lingua di quella Città Illustrissima,

eccetto uno spagnuolo, il qual per essere

un bravazzone, non ha trovato (credomi)

chi gli dia lingua, ond'è la sua restatali:

forse per farvi ancor con essa ridere. ${ }^{11}$

(The scene is set in Pisa. Those who will appear / are foreigners, but they will seem / Florentines to you, because they have learned so well the most sweet / language of that most illustrious city; / except for a Spaniard who, being / a great big bully, has found no-one, I think, / who might teach him the language; and so he is left with his own, / perhaps so that you can laugh at him for it.)

The detested Spanish garrison soldier Ignico, thus speaks his own language, a comic mix of Spanish and Italian that leads to inevitable confusions and derision. In a long bilingual scene with the Tuscan meddlesome greengrocer Sgalla, his rival in love, and the old doctor Basilio, Ignico's words are constantly twisted for comic effect (III.4). When he approaches Sgalla, he greets him with the question:

Sis vos

quel' hombres tam hornando che andes

buscando un Cavalier com'io, per fare

con iglio à scuregliadas?

(Are you that honourable man who is looking for a knight such as me to make him shit his pants [in fear] ? ${ }^{12}$ )

\footnotetext{
${ }^{11}$ BCI, MS I.VII.24, fol. 130v. I thank Elena Brizio (Medici Archive Project) and Renzo Pepi (Biblioteca Comunale degli Intronati di Siena) for facilitating my consultation of the Sienese manuscript. I have chosen to transcribe from the Sienese manuscript rather than from the 1856 edition by Gaetano Milanesi because the latter hypercorrects the text to such an extent that it becomes unreliable for my discussion of Cecchi's language.

12 BCI, MS I.VII.24, fol. 149r. Milanesi mistranscribes the passage as: "Soys vos / Aquel hombre tan honrade que andais / Buscando un cavallero come yo por hacer / Con illo à sus reilliadas?”. In so doing, Milanesi not only fails to catch the humour of the mangled Italian/ Spanish language spoken by Ignico or his vulgar scatological reference, but also introduces
} 
While Ignico is trying to frighten Sgalla with his blustering challenge and foul language, the greengrocer mocks him and, catching the phrase "con iglo" (a Hispanization of the Italian, con egli, "with him"), either consciously or unconsciously misunderstands it as "coniglio" (Ital., rabbit). Immediately fearing for the reputation of his shop, Sgalla responds in a huff:

\author{
Non ne tengo \\ di conigli in bottegha, Signor no. \\ Gli lascio a voi tener ch'havete dove. \\ M'havete colto in cambio.
}

(I don't / keep rabbits in my shop, no sir! / I let you keep them, you've got the place for them. / You've mistaken me for someone else.)

By suggesting that Ignico has plenty of room to "keeps rabbits" Sgalla is, in fact, suggesting that the soldier is timid and fearful of everything — the Italian idiom essere un coniglio (to be a rabbit) is the equivalent of the English idiom "to be chicken." Ignico, however, fails to catch the insult and carries on, with determination and his usual mixture of Italian and Spanish:

In canbir? Non te

hos in cambio tomado, no; ben sis

vos aglio que chero io.

(Someone else? No, I / did not mistake you for someone else; You are / definitely the one I'm looking for.)

At this, the old doctor Basilio, who had been standing by, misunderstands the Hispanicized egli (rendered by Ignico as aglio) as the Italian aglio, and concludes that the soldier is asking for garlic. As the misunderstandings across linguistic fracture lines increase, the figure of the braggart soldier unable to communicate

a transcription error (sus reilliadas) that he is unable to resolve. The word reilliadas, in fact, does not exist in Spanish. I would like to thank the many Hispanist colleagues I consulted for confirming that reilliadas is incomprehensible. Cecchi's original word, scuregliadas, is instead a humorous Hispanization of the Italian scoreggia (fart); I have thus translated the idiom "fare a scoreggie" ("to make farts") with the more idiomatic English phrase "to shit one's pants." 
his wishes (or unable to have the locals take him seriously) grows ever more comic, while the affirmation of the Tuscan idiom as the only vernacular able to carry a clear, logical message grows ever stronger.

No matter who is speaking, all foreign idioms present in Cecchi's plays are, ultimately, trumped by the local Florentine vernacular, which Cecchi privileges at every turn. In the prologue to Il medico (1557) he points out that, while most of the characters in the play are foreigners, they have nonetheless learned to speak Florentine, some because they have been resident in Florence for many years, others because they have learned the language from "good authors" (buoni autori),

e ciò a perpetua gloria

Di voi, Toscani: poichè la dolcissima

Favella vostra ha oggi e scuole pubbliche

Ed accademie favorite e nobili.

(Il medico, p. 240)

(and this to the eternal glory / of you, Tuscans: for your sweetest / language today has both public schools / and much favoured noble academies.)

Cecchi is certainly not alone in trumping the superiority of the Florentine idiom. His fellow Tuscan Giovan Battista Cini (born in 1538 in Pisa, but soon part of the Florentine cultural milieu), was just as strong a supporter of Florentine linguistic superiority - in the prologue to his La vedova (1566-69), a play that features characters speaking various Italian dialects (among which Bergamasque, Venetian, Neapolitan, and Sicilian), the allegorical figure of Riso ("Laughter") first claims that the author has used various foreign idioms in order to provide some levity for the spectators:

A cagion solo di render la sua Favola

Più festosa, l'usar diverse lingue,

Ma però tutte Italiane; \& pel lungho

Uso assai intelligibili. [...]

[...] tal l'ha scelte anche a posta

Per far ridere

(Cini, La vedova, pp. 6-7). 
Words, Characters, and Context:

Giovan Maria Cecchi and the Language of Theatre

(Only in order to render his story more festive [the author chose] to use several languages but all of them Italian and all very intelligible because of long use [...] he chose them also in order to make people laugh).

Then, drawing the audience's attention to the fact that ancient Greek dramatists also used a variety of languages in their plays, Riso adds:

Dio sa, quel che pareva

A quei d'Athene, ch'havean sopra gl'altri

La Palma; come oggi in Italia voi

Toscani il parlar Ionico, o Eolico.

(Cini, La vedova, pp. 7-8)

(God knows what Ionic or Aeolic speech must have sounded like to the people of Athens, who stood first among the rest as today in Italy you Tuscans do).

In privileging the Florentine vernacular and promoting it as first among the various Italian idioms, both Cecchi and Cini were inserting themselves into a long tradition that included the likes of Dante and Boccaccio in the fourteenth century, Lorenzo de' Medici in the fifteenth, and Niccolò Machiavelli in the earlier part of the sixteenth century. They were also firmly in line with Duke Cosimo I de' Medici's cultural agenda that aimed to make Florence, in particular, and Tuscany, in general, the cultural and linguistic capital of Italy. ${ }^{13}$

In Cecchi's plays language is also attuned to the age and condition of the characters that use it. And so, the elderly miser speaks in mercantile terms using a language of commerce that echoes Florentine business vocabulary. The farmer from the countryside uses agricultural idioms and metaphors. And the young lover speaks in a poetic Tuscan full of Petrarchan images that, at times, leave him open to the mockery of his more pragmatic and less literate servant. For example, in the comedy L'assiuolo (1549), when Giulio, the young man in love with a married woman, confides his love and his difficulties to his wily servant Giorgetto, the latter is quite surprised by Giulio's ineffectual flights of love-torn sentiments and especially by Giulio's inability to connect, both verbally and physically, with the beloved. Giorgetto exclaims "E' sono duoi mesi che voi vi innamoraste di lei,

\footnotetext{
${ }^{13}$ For Cosimo I's cultural agenda, see, among others, Eisenbichler, The Cultural Politics.
} 
e non le avete ancor fatto parlare? O dappochi!" (You've been in love with her for two months and you haven't let her know yet? What a good-for-nothing!"). To Giulio's answer that "Le son cose che non si gettano in pretelle" (Such matters must follow their own course"). Giorgetto quips "Had I been in your shoes, she would have been a month and a half on her course." ("Se io fussi stato ne' piedi vostri, a quest'ora io vorrei che la fusse grossa d'un mese e mezzo.")..$^{14}$

Sexual innuendos such as Giorgetto's, which clearly must have been accompanied by appropriate gestures (in this case a large stage gesture indicating pregnancy), could raise not only laughter, but also eyebrows, depending on the audience. Cecchi is thus sensitive to his public and careful to adapt the language of his plays both to the occasion and to the audience. The secular comedy L'assiuolo was composed for performance at Carnival time by young men in festive brigate, in this case the Compagnia de' Monsignori, also known as i Fantastichi. ${ }^{15}$ These were groups of young men who gathered on a yearly basis to organize some sort of entertainment for Carnival, such as a play, a parade float (trionfo), a minstrel group. The Medici sponsored brigate of the Broncone and the Diamante, active in the earlier part of the century and famous for the trionfi they staged in the carnival of 1513, are two of the most well known and are often referenced in studies on Florentine festive life or carnival songs (canti carnascialeschi) ${ }^{16}$ Such a context - young men having fun at Carnival - not only allowed, but even encouraged sexual innuendoes such as Giorgetto's. To further heighten the erotic context, Cecchi's L'assiuolo also had a definite goliardic component - it brought to the stage the successful rouse used by two first-year students at the university of Pisa that allows them to sexually seduce two respectable married women in town. The university setting and the prank devised by the two students also offered the opportunity for a good number of erotic allusions.

Like Machiavelli's La mandragola, Cecchi's L'assiuolo also ends in a sexually unconventional manner - not with a marriage, but with an adultery. In sixteenth-century learned comedies, as in ancient Graeco-Roman comedies, marriage was the only acceptable solution to the love stories of the young $a d u$ lescens in the play. Their eventual and legitimate union resolved the impasse that had blocked the action at the start of the play and raised the conundrums that

\footnotetext{
${ }^{14}$ Cecchi, L'assiuolo, I.i, p. 131; English translation from Cecchi, The Horned Owl, p. 6

${ }^{15}$ See the prologue to Cecchi, L'assiuolo, p. 128.

${ }^{16}$ See, among others, Ciappelli, Carnevale e Quaresima, 199, 284.
} 
provided the "humour" in the course of the comedy. Their marriage was thus a requirement of the denouement because it not only resolved the impasse, but also served as a moral lesson and as a reaffirmation of societal values. Not so with Cecchi's L'assiuolo or Machiavelli's La mandragola - they both end with the consummation of an adulterous relationship and the establishment of a longterm extra-marital affair that was to remain undetected by the cuckolded husband. Cecchi's play actually trumps Machiavelli's on two grounds: first, because the play ends not with one, but two adulteries and, second, because neither student in the play promises marriage to his new-found mistress should she eventually remain widowed of her husband (which is what Callimaco promises Lucretia in La mandragola). In fine goliardic spirit, Giulio and Rinuccio have not only successfully seduced two married women and cuckolded their respective husbands, but also set up an adulterous relationship that will see them through their university years. In modern terms, they have managed to find two good "friends with benefits."

As the sixteenth century moved into its second half and as the religious climate of Tuscany in particular and Italy in general began to change as a consequence of the religious and moral reforms emanating from the Council of Trent, so did Cecchi's theatre. The language in his plays adapted to the changing times and audiences. By the 1560s-70s, Cecchi stopped writing for carefree, carnival-time brigate such as the Fantastichi and began to write instead for adolescent males in lay religious confraternities or for nuns and novices in convents. ${ }^{17}$ As a result, he was obliged to revise his language to fit not only the times, but also the nature of the performers, the audience, and the place where the plays were being staged.

While we find that for young men in religious confraternities Cecchi did continue to draw on a language that was, to some extent, still sexually allusive (though not as much as the language he used in the secular learned comedies he composed in the 1540s-50s), in the case of plays to be staged by young women in convents the language and the dramatic situations became much tamer,

\footnotetext{
${ }^{17}$ For plays in youth's confraternities, see Eisenbichler, The Boys of the Archangel Raphael, especially chapters 16-17; Polizzotto, Children of the Promise; and Taddei, Fanciulli e giovani. For plays in nun's convents, see especially Weaver, Convent Theatre; but also the introductions to Pulci, Florentine Drama and idem, Saints' Lives; more generally on nuns in Florence, see Strocchia, Nuns and Nunneries, and Lowe, Nuns' Chronicles.
} 
expurgated as it were of anything that might be deemed to be sexually allusive or just simply vulgar. Cecchi's L'acqua vino, a three-act play on the miracle at Cana, is a case in point. Its ten extant manuscripts reveal that there are clearly two, possibly three different versions of this work. ${ }^{18}$ The original version was composed for performance during the Carnival of 1579 by adolescent males in the youth confraternity of St. John the Evangelist, a group that had already mounted some of Cecchi's plays, both secular and religious. ${ }^{19}$ A few years later (probably in 1585), Cecchi revised the play for performance during Lent by novices in a Florentine convent. ${ }^{20}$ Not surprisingly, in the prologue to the version for convent

\footnotetext{
${ }^{18}$ Briefly put, the prose version published by Michele Dello Russo in 1869 is the original version of the play performed by the youths of the confraternity of St. John the Evangelist during the Carnival of 1578 (Florentine style, 1579 modern style). The version in verse published by Crescentino Giannini in 1876 (and reprinted in 1878) is, instead, the revised play performed by novices and nuns in a convent in Florence during Lent in, probably, 1585. According to Jacqueline Brunet a third version of the play, still unpublished, survives in a manuscript at the Biblioteca Marciana in Venice that "présente un texte qui fait résulement bande à parte" (Brunet, "L'acqua-vino," p. 143). For a detailed analysis of the various versions and manuscripts, see Brunet, "L'Acqua-Vino."
}

The ten manuscripts of the play are as follows: five at the Biblioteca Comunale degli Intronati di Siena, MS H.XI.56, fols. 36 $-74^{\mathrm{r}}$; MS H.XI.59, fols. $1^{\mathrm{r}}-23^{\mathrm{r}}$ (with autograph signature of his son, Niccolò Cecchi); I.VII.25, fols. 29-48 ; MS I.VII.25, ff. 49r-77r; MS I.VII.25, fols. $79^{\mathrm{r}}-103^{\mathrm{r}}$; two at the Biblioteca Nazionale Centrale di Firenze, MS Magliab. VII.979, fols. 289 $-319^{\mathrm{r}}$ and MS Magliab. II.VII.9, (old numbering, Magl. Cl. VII, n. 1226) pp. 289-369; one at the Biblioteca Riccardiana in Florence, MS 2818, fols. 277 ${ }^{\mathrm{r}}-324^{\mathrm{r}}$; one in the private collection of the marchese Rosselli del Turco in Florence, MS 44; and one at the Biblioteca Marciana in Venice, MS It. IX.298, 6076, fols. $1^{\mathrm{r}}-71^{\mathrm{r}}$ unnumbered.

19 The Compagnia del Vangelista, as it was popularly known in Florence, had previously mounted Cecchi's secular play Il donzello (in 1555), as well as his only tragedy, La morte del re Acab (1559), his sacred drama La coronazione del re Saul (in 1569), and his farsa (that is, three-act play) La serpe ovvero la mala nuora (in 1574). Later it would mount the sacred drama L'esaltazione della croce (in 1589), the "moral comedy" Lo sviato (in 1592), and the learned comedy I dissimili (in 1627), all after Cecchi's death (1587). For plays performed at the Vangelista, see Eisenbichler, "Per un nuovo approccio"; idem, "Saint or Politician?", and idem. "Confraternities and Carnival." For lay sermons recited in this confraternity, see Cecchi, Ragionamenti spirituali and Eisenbichler, "A Playwright in the Pulpit."

${ }^{20}$ It is not clear which Florentine convent performed the second version of the play. I would suggest that it probably was the Dominican convent of Santa Caterina da Siena where two of Cecchi's nieces, Francesca and Cecilia (both daughters of his brother Baccio) had taken the veil and for which convent Cecchi composed at least four plays in the immediately preceding 
performance, Cecchi feels the need to explain that one can make an audience laugh without necessarily having recourse to improper words or actions ("Chè ben si può, sanza far atti o dire / Parole disoneste, anco far ridere." L'acqua vino, p. 7). Cecchi's comment suggests that, normally, plays did rely on stage action and "dishonest words" to elicit laughter from the audience — perhaps a reference to the Commedia dell'Arte troupes that were enjoying great success at the time, but possibly also a reference to his own earlier works for the stage. The comment also points out that Cecchi was aware of current discussions on whether a play could be amusing without, necessarily, being vulgar in word or deed. ${ }^{21}$ Cecchi claimed this could be done and to prove it revised his L'acqua vino to make it suitable for nuns. To do so, he removed all references that could have been interpreted as obscene or sexual and any action that might have been deemed vulgar. The process entailed a drastic reduction in the number of local proverbs and slang terms used in the play, a cleaning up of bad language, and the removal of references to drunkenness and voraciousness.

What remained problematic, however, was the very fact that nuns were putting on a play. In L'assiuolo (1549), Cecchi had brought to the stage an old man who strongly disapproved of nuns performing plays. On meeting his sister-in-law Violante with a bundle of clothes to be used by nuns in a convent as costumes for a play they were to perform the following day, the old lawyer Ambrogio grumbles and complains about such diversions in a nun's daily routine; then, catching sight of men's clothes in the bundle, he becomes horrified at the sight of coloured stockings and stuffed codpieces, and jumps to the conclusion that there is wickedness afoot:

Ambrogio. Che tante commedie, o non commedie? che ci avete stracco voi, e loro; se l'avessino bisogno, come le dicono, ell'attenderebbono ad altro che a commedie. Son temporali da commedie questi, eh? lascino fare le commedie al Duca, e alla compagnia de' Cardinali, e attendino a filare.

Violante. $\mathrm{O}$ al nome di Dio. Messer Ambrogio, le poverette sono pur di carne e d'ossa come noi, e l'hanno pur a aver qualche spasso; che volete voi che le faccino?

years - Il Tobia (Nov. 1580), La conversione della Scozia (also known as L'Eduina, 1581), Sant'Agnese (March 1582), and the now lost Santa Cecilia (1583); for the dating of the plays, see Ferraro, "Catalogo," pp. 57-58, 71.

${ }^{21}$ Weaver, Convent Theatre, passim. 
Ambrogio. I' sono stato per dirtelo. Che soffoggiata è questa?

Violante. Panni, che io ho accattati loro.

Ambrogio. Mostra qua: togli! e' ci sono fino alle calze chiuse frappate: guarda qua, che braghettacce intirizzate! e portate voi anco queste ne' munisteri?

Violante. Che? vorreste che le portassimo da mattaccini?

Ambrogio. I' dubito, che queste non sieno da pazzi, e cattivi.

Violante. O gran cosa! sempre voi pensate a male.

$$
\text { (L'assiuolo, III.4, pp. 161-62) }
$$

(Ambrogio: Comedies, comedies, comedies. I've grown tired of them, you and your nuns. If they were in need, and they say they are, they should tend to other things, and not comedies. Is this the time to put on comedies, eh? They should let the Duke's company or the Cardinal's put on comedies, and they should stick to weaving.

Violante: In God's name, Messer Ambrogio! The poor girls are made of flesh and bones just like us and they must have some relaxation after all. What do you want them to do?

Ambrogio: I just told you. [Catching sight of the bundle of clothes] And what's this?

Violante: Some clothes I bought for them.

Ambrogio: Here, let me see. Goodness! There's even men's coloured stockings here! And, look, breeches! And you're taking these things to the convent?

Violante: What? Do you want me to take them to the madhouse?

Ambrogio: That's right, they're just right for mad and wicked people.

Violante: That's something! You immediately jump to the worst conclusions.

(The Horned Owl, III.4, pp. 38-39)

Old man Ambrogio is clearly a comic figure who serves as the butt of the play's humour, but perhaps he is not too far removed from what, a few years later, would be the driving forces at the Council of Trent that prohibited the performance of plays in convents or other religious institutions. ${ }^{22}$

\footnotetext{
${ }^{22}$ For a discussion of the Church's efforts to curb and curtail theatrical performances in religious institutions, see, among others, Eisenbichler, The Boys of the Archangel Raphael, pp. 218-24.
} 
We can see this change in cultural atmosphere in the prologue for the revised version of L'acqua vino, where Cecchi felt obliged to introduce an apology for secular diversions in religious institutions for women (something that he seems not to have deemed necessary in the original version composed for young males in a confraternity). To explain the need for such diversions, the new prologue recounted the story of St. Benedict and the archer — when a hunter passing by Benedict's monastery was surprised to see the monks playing a ball game, St Benedict explained that they, too, needed some relaxation, just like the hunter's bow which, if kept taut all the time, would eventually lose its strength and become useless. With this story Cecchi was pointing out that St Benedict himself, founder of one of the greatest, strictest, and most successful orders of the Christian Church, was profoundly aware of the fact that, in order to keep his monks strong and vibrant in their devotions, he needed to provide them with opportunities to relax and release tension, such as playing ball games. ${ }^{23}$ As Cecchi's new prologue points out, nuns in a convent also needed to have some relaxation in order to then be able to return to their devotions with greater energy. The performance of plays inside convent walls and even attendance at these plays provided the nuns with the necessary break from the usual routine, especially in Lent, when devotions (both spiritual and physical) were more demanding.

By changing with the times, Cecchi was able to remain popular with his audiences, so much so that he remained a much sought-after dramatist till the end of his life. His careful attention to the language of theatre and his unfailing promotion of the local vernacular reached out to his audiences and captivated them. His success, so decried by Antonfrancesco Grazzini, was founded in part on his finely tuned ear for the colourful local expression or the strange foreign idiom, but also on his ability to create stage characters whose own particular vocabulary helped to create a recognizable type, whether it be the grumpy old man or the preposterous braggart soldier, the wily servant or the enamoured young man. In highlighting the expressive richness of the Tuscan vernacular Cecchi was also participating in the larger Florentine project of advancing its local idiom as the national language of Italy. By bringing to the stage and, in a way, foregrounding the region's semantic richness Cecchi was promoting Florentine as the ideal and most expressive idiom

\footnotetext{
${ }^{23}$ The story of St. Benedict and the archer is used also in the prologue of L'acquisto di Giacobbe (post 1580) performed by nuns in a unidentified convent and in Il putto risuscitato (post 1580) performed by youths in the "Compagnia dell'Angelo custode."
} 
of communication for everyone in the peninsula. Not surprisingly, his plays were soon mined by the Accademia della Crusca for their ground-breaking dictionary and, three centuries later, recommended by the Ministry of Education as effective tools for the teaching of "good" Italian in the schools of recently united Italy. His language, so firmly tied to his roots and to the social context of late Renaissance Florence, had helped to turn a local vernacular into a national language and to provide that language with a plethora of words and idioms.

Victoria College, University of Toronto

\section{Cited Works}

\section{Manuscript Sources}

Siena, Biblioteca Comunale degli Intronati (BCI)

MS I.VII.24, fols. 129-174, Giovan Maria Cecchi, I rivali.

\section{Printed Sources}

Brunet, Jacqueline. "Ces mots en cusse et en osse ... et quelques autres: dialectes et langues étrangères dans le théâtre de G.M. Cecchi." Culture et société en Italie du Moyen Age à la Renaissance. Paris: Université de la Sorbonne Nouvelle, 1985, pp. 353-63.

"Le Paysan et son langage dans l'oeuvre théâtrale de Giovanmaria Cecchi." In Ville et campagne dans la littérature italienne de la Renaissance. Vol. 1: Le Paysan travesti. Ed. A. Rochon. Paris: Université de la Sorbonne Nouvelle, 1976, pp. 179-267.

. "L'Acqua-vino : une (deux ou trois ?) farce(s) de G. M. Cecchi." In Culture et religion en Espagne et en Italie aux XVe et XVIe siècles, ed. Manuel Ballestro et al. Abbeville: Imprimerie F. Paillart, 1980, pp. 141-74.

Cecchi, Giovan Maria. Datan e Abiron. In idem, Drammi spirituali inediti, ed. Raffaello Rocchi. Florence: Successori Le Monnier, 1900, vol. 2, pp. 221-97. I contrassegni, ed. Bruno Ferraro. Bologna: Commissione per i testi di lingua, 1986.

. I rivali. In idem, Commedie, ed. Gaetano Milanesi. Florence: Felice Le Monnier, 1856, vol. 1, pp. 181-285. 
Words, Characters, and Context:

Giovan Maria Cecchi and the Language of Theatre

. Il cieco nato. In idem, Drammi spirituali inediti, ed. Raffaello Rocchi. Florence: Successori Le Monnier, 1900, vol. 2, pp. 299-376.

. Il donzello. In idem, Commedie, ed. Gaetano Milanesi. Milan: Gio. Silvestri, 1850, vol. 2, pp. 293-365.

. Il figliuol prodigo. In idem, Commedie, ed. Gaetano Milanesi. Florence:

Felice Le Monnier, 1856, vol. 1, pp. 1-69.

Il medico, ovvero il Diamante. In idem, Commedie inedite, ed. Giovanni

Tortoli. Florence: Barbèra, Bianchi e Comp., 1855, pp. 237-345.

Il putto risuscitato. In idem, Drammi spirituali inediti, ed. Raffaello

Rocchi. Florence: Successori Le Monnier, 1895, vol. 1, pp. 351-88.

Il Tobia. In idem, Drammi spirituali inediti, ed. Raffaello Rocchi.

Florence: Successori Le Monnier, 1895, vol. 1, pp. 1-91.

L'acqua vino, ed. Crescentino Guerrini. Ferrara: Domenico Taddei e figli, 1876.

. L'acqua vino. In idem., Commedie, ed. Michele Dello Russo. Naples:

Francesco Ferrante, 1869.

L'acquisto di Giacobbe. In idem, Drammi spirituali inediti, ed. Raffaello

Rocchi. Florence: Successori Le Monnier, 1895, vol. 1, pp. 93-160.

L'ammalata. In idem, Commedie, ed. Gaetano Milanesi. Florence:

Felice Le Monnier, 1856, vol. 1, pp. 89-179.

L'assiuolo. In Commedie del Cinquecento, ed. Nino Borsellino. Biblioteca

di classici italiani, 9. Milan: Feltrinelli, 1962, pp. 121-94.

La coronazione del re Saul. In idem, Drammi spirituali inediti, ed.

Raffaello Rocchi. Florence: Successori Le Monnier, 1900, vol. 2, pp. 5-123.

La dote. In idem, Commedie, ed. Olindo Guerrini. Milan: Edoardo

Sonzogno, 1883, pp. 17-71.

. La gruccia. In idem, Drammi spirituali inediti, ed. Raffaello Rocchi.

Florence: Successori Le Monnier, 1895, vol. 1, pp. 263-350.

La serpe ovvero la mala nuora. In idem, Drammi spirituali inediti, ed. Raffaello Rocchi. Florence: Successori Le Monnier, 1900, vol. 2, pp. 151-219.

. Le maschere e Il Samaritano. Florence: Giuseppe di Giovacchino Pagani, 1818.

. Lo spirito. In idem, Commedie, ed. Gaetano Milanesi. Milan: Gio. Silvestri, 1850, vol. 2, pp. 367-428. 
Ragionamenti spirituali (1558), ed. Konrad Eisenbichler. Ottawa: Dovehouse Editions, 1986.

The Horned Owl (L'Assiuolo), trans. Konrad Eisenbichler. Carleton Plays in Translation, 3. Waterloo: Wilfrid Laurier University Press, 1981. Revised and reprinted in Donald Beecher, ed., Renaissance Comedy. The Italian Masters. The Lorenzo Da Ponte Italian Library. Toronto: University of Toronto Press, 2009, vol. 2, pp. 221-88.

Ciappelli, Giovanni. Carnevale e Quaresima. Comportamenti sociali e cultura a Firenze nel Rinascimento. Temi e testi, n.s. 37. Rome: Edizioni di storia e letteratura, 1997.

Cini, Giovan Battista. La vedova commedia. Rappresentata à honore del Serenissimo Arciduca Carlo D'Austria nella venuta sua in Fiorenza L'anno MDLXIX. Florence: Giunti, 1569.

Considine, John. Academy Dictionaries, 1600-1800. Cambridge, UK: Cambridge University Press, 2014.

Eisenbichler, Konrad. "A Playwright in the Pulpit: The Spiritual Discourses of Giovan Maria Cecchi (1558).” Italian Culture 6 (1985): 77-88. "Confraternities and Carnival: The Context of Lorenzo de' Medici's Rappresentazione di Giovanni e Paolo," Comparative Drama 27:1 (1993), pp. 128-39. Published contemporaneously in Medieval Drama on the Continent of Europe. Ed. Clifford Davidson and John H. Stroupe. Kalamazoo: Medieval Institute Publications, Western Michigan University, 1993, pp. 128-39. "Per un nuovo approccio all'Abram e Isac di Feo Belcari." In Cultura e potere nel Rinascimento. Atti del IX convegno internazionale (ChiancianoPienza, 21-24 luglio 1994, ed. Luisa Secchi Tarugi. Florence: Franco Cesati Editore, 1999, pp. 293-300.

- "Saint or Politician? The Ambivalence of the Converted in Lorenzo de’ Medici's Rappresentazione di Santi Giovanni e Paolo.” Mediaevalia 26:1 (2006):121-33.

. The Boys of the Archangel Raphael: A Youth Confraternity in Florence, 1411-1785. Toronto: University of Toronto Press, 1998. . The Cultural Politics of Duke Cosimo I de' Medici. Ed. and Intro. by Konrad Eisenbichler. Aldershot, UK: Ashgate, 2001.

Fiacchi, Luigi. Dei proverbi toscani, lezione di Luigi Fiacchi detta nell'Accademia della Crusca il di 30 novembre 1813. Con la dichiarazione de’ proverbi di Gio. 
Words, Characters, and Context:

Giovan Maria Cecchi and the Language of Theatre

Maria Cecchi, testo di lingua citato dagli Accademici della Crusca. Florence: Piatti, 1818

Ferraro, Bruno. "Catalogo delle opere di G.M. Cecchi." Studi e problemi di critica testuale 23 (1981): 39-75.

Grazzini, Anton Francesco. Le rime burlesche. Florence: G.C. Sansoni, 1882.

Lombardi, A. "Il prologo degl'Incantesimi e la Dolcina di G.M. Cecchi." Giornale storico della letteratura italiana 3 (1884): 74-78.

Lowe, K.J.P. Nuns' Chronicles and Convent Culture in Renaissance and CounterReformation Italy. Cambridge, UK: Cambridge University Press, 2003.

Polizzotto, Lorenzo. Children of the Promise. The Confraternity of the Purification and the Socialization of Youths in Florence, 1427-1785. Oxford-Warburg Studies. Oxford: Oxford University Press, 2004.

Pulci, Antonia. Florentine Drama for Convent and Festival. Seven Sacred Plays, transl. James W. Cook, ed. James W. Cook and Barbara Collier Cook. Chicago: University of Chicago Press, 1996.

. Saints' Lives and Bible Stories for the Stage, trans. James Wyatt Cook, ed.

Elissa B. Weaver. The Other Voice in Early Modern Europe: The Toronto

Series, 7. Toronto: Iter Inc. / Centre for Reformation and Renaissance Studies, 2010.

Strocchia, Sharon. Nuns and Nunneries in Renaissance Florence. Baltimore: Johns Hopkins University Press, 2010.

Taddei, Ilaria. Fanciulli e giovani. Crescere a Firenze nel Rinascimento. Florence: Leo S. Olschki, 2001.

Weaver, Elissa B. Convent Theatre in Early Modern Italy. Spiritual Fun and Learning for Women. Cambridge, UK: Cambridge University Press, 2002. 
